\title{
Up Against the Clock: \\ Migrating to LibGuides v2 \\ on a Tight Timeline
}

\section{ABSTRACT}

During Fall semester 2015, Librarians at the United States Naval Academy were faced with the challenge of migrating to LibGuides version 2 and integrating LibAnswers with LibChat into their service offerings. Initially, the entire migration process was anticipated to take almost a full academic year; giving guide owners considerable time to update and prepare their guides. However, with the acquisition of the LibAnswers module, library staff shortened the migration timeline considerably to ensure both products went live on the version 2 platform at the same time. The expedited implementation timeline forced the ad hoc implementation teams to prioritize completion of the tasks that were necessary for the system to remain functional after the upgrade. This paper provides an overview of the process the staff at the Nimitz Library followed for a successful implementation on a short timeline and highlights transferable lessons learned during the process. Consistent communication of expectations with stakeholders and prioritization of tasks were essential to the successful completion of the project.

\section{INTRODUCTION}

Academic libraries all over the United States have migrated from LibGuides version 1 to the new, sleeker, responsive design of version 2 . Approaches to the migration can differ vastly depending on library size, staff capabilities and time frame available for completing the project. In 2015, the Nimitz Library at the United States Naval Academy, began planning to both upgrade LibGuides to version 2 and to acquire LibAnswers with LibChat. The Web Team and Reference Department partnered to migrate the LibGuides platform and integrate LibAnswers into the Library's web presence.

The Library first adopted Springshare's LibGuides in 2009. By 2015, the subscription had grown to 61 published guides with 10,601 views. The LibGuides collection was modified and expanded during two web site upgrades and several staffing changes. Throughout 2014 and 2015, Library staff periodically discussed the possibility of upgrading to the version 2 interface, but timing,

Brianna Buljung (bbuljung@mines.edu) is Instruction \& Research Librarian, Colorado School of Mines, Golden, CO. Catherine Johnson (cjohnson@usna.edu) is Head of Reference \& Instruction at the United States Naval Academy, Annapolis, MD. 
staffing vacancies and the priority of other projects kept the migration from taking place. In late summer 2015, with the acquisition of Springshare's LibAnswers with LibChat pending, staff determined that it was finally time to migrate to the new LibGuides interface.

Initially, the migration team planned to spend nearly a full academic year completing the migration process. This timeline would provide guide owners with ample time for staff training, revising guides, conducting usability testing and preparing the migrated guides to go live without distracting from their other duties. However, right before starting the project, the Library finalized the acquisition of Springshare's LibAnswers with LibChat which they decided to launch with the version 2 interface. The team pushed up the LibGuides migration by several months to keep from confusing patrons with multiple interfaces and launch dates. The migration of LibGuides and the implementation of LibAnswers would take place during the Fall semester and both products would go live in the version 2 interface before the start of the Spring semester. This paper provides an overview of the process that the staff at Nimitz Library followed for a successful implementation on a short timeline and highlights transferable lessons learned during the process. The authors also include a post-implementation reflection on the process.

\section{LITERATURE REVIEW}

Much of the currently available literature on migration of platforms, especially the LibGuides platform is published informally. Librarians from universities across the country have created help guides, checklists and best practices for surviving the migration. Most migration help-guides are tailored to each specific institution but they can still provide helpful suggestions that can be adapted by another. ${ }^{1}$ Springshare also provides extensive help content and checklists, including a list of the most important steps for administrators to complete. ${ }^{2}$ However, little of the available literature discusses the minimally acceptable amount of work needed to be completed by guide authors. This type of information was crucial to the Nimitz Library team after drastically shortening the migration timeline. A clearly delineated list of required and optional tasks was needed for guide owners, given time constraints and other job duties.

In addition to the informally published help materials, several articles have been published on various aspects of research guide design and evaluation. A few articles examine the migration process. Hernandez and McKeen offer advice for libraries contemplating migration; including setting goals and performing usability testing against the new guides. ${ }^{3}$ Duncan et al provide a case study of the implementation process at the University of Saskatchewan. ${ }^{4}$ Some articles discuss the basics of guide design and usage in the library. These best practices can be adapted to different platforms, web sites and user populations. They discuss the importance of various web design elements such as word choice and page layout. ${ }^{5}$ Another aspect the literature exposes is student use of the guides. ${ }^{6}$ Finally, usability of research guides is one of the most important and widely discussed topics in the literature. Creating and maintaining guide content depends on the user's ability to locate and use the guides in their research.7 ${ }^{7}$ Most often, research guides are designed 
with the student in mind; to assist them in beginning a project, researching when a librarian is unavailable or as a reference for follow-up after an instruction session. ${ }^{8}$ As Pittsley and Memmott discuss, navigation elements can impact a student's use of research guides. ${ }^{9}$

\section{The Process}

As preparations for the migration began, it became immediately apparent that the Web Team and Reference Department would have to divide the project into manageable segments to complete the work without overwhelming guide owners. Three ad hoc teams, made up of librarians from several different departments, were created to take the lead on different elements of the project. The migration team was responsible for researching, organizing and supervising the migration of LibGuides to version 2. The LibAnswers team learned about LibAnswers and how to effectively integrate the product into the Library's web site. The LibChat team tested the functionality of LibChat and determined how it would fit into the Library's reference desk staffing model. Dividing the project into manageable segments allowed each team to focus on the execution of their area of responsibility. The team approach allowed the Library to draw on individual strengths and staff willingness to participate without depending on one single staff member to manage the entire migration and implementation process on such a short timeline.

\section{Migration Team}

The migration team was responsible for determining the tasks that were mandatory for guide owners to complete, the amount of training they would need to use the new interface and how each product should be incorporated into the Library's web site. The LibGuides migration team relied heavily on advice from other libraries and the documentation from Springshare to guide them in determining mandatory tasks. The Engineering and Computer Science librarian reached out to the ASEE Engineering Libraries Division listserv for advice from peer libraries that had already completed migration. The team also made use of the Springshare help guides and best practices guides posted by other universities.

Ultimately, the migration team created checklists and spreadsheets to help guide owners prepare their guides for migration. A pre-migration checklist (Appendix A) was shared with guide owners; containing all of the required and optional tasks that needed to be completed before the migration took place in early November. Tasks such as deleting outdated or unused images and evaluating low use guides for possible deletion were required for guide owners to complete. Other tasks such as checking each guide for a friendly url or checking database descriptions for brevity and jargon free language were encouraged but considered optional. The team determined that items directly related to the ability of post-migration guides to function properly made the required list, while more cosmetic or stylistic tasks could be completed on a time-allowed basis. A post-migration checklist (Appendix B) was created for guide owners following the migration. This list included portions of the guides that had to be checked to ensure widgets, links and other assets had 
migrated properly. Both checklists were accompanied by tips, screenshots, deadlines and indicated which team member to contact with questions. Clear explanation of the expectations for the project, and accommodating the guide owners' busy schedules made the migration more successful.

The migration team gave the new, more robust A-Z list significant attention. LibGuides version 2 allows the A-Z list to be sorted by subject, type and vendor. It also allows a library to tag "Best Bets" databases in each subject area. The databases categorized as Best Bets display more prominently in the list of databases by subject. Using Google Sheets, the Electronic Resources Librarian quickly and easily solicited feedback from liaison librarians about which databases to tag as Best Bets for each subject area. Google Sheets also made it easy for librarians to edit the list of databases related to their subject expertise. Some databases had been incorrectly categorized and, in some subjects, newer subscriptions didn't appear on the list.

LibGuides version 2 allows users to sort databases by type, but doesn't provide a predetermined list of types. In order to create the list of material types into which all databases would be sorted, the migration team examined lists found on other library web sites. Several lists were combined and duplicates, or irrelevant types were removed. An additional military specific type was added to address the most common research conducted by midshipmen. Then, the liaison librarians were solicited for input on the language used to describe each type and which databases should be tagged by each type. Name choices are a matter of local preference, such as having a single type category for both dictionaries and encyclopedias, or two separate categories. To keep the list of material types to a manageable length, the team decided that each type must contain more than one or two databases. It takes time to get well defined lists of subjects and types. Staff working with patrons are able to gather informal feedback about the categorizations in their current form, and make suggestions, corrections, or additions based on patron feedback.

The migration of LibGuides and acquisition of LibAnswers provided the Reference Department and Web Team with an opportunity to update policies and establish new best practices for guide owners. One important cosmetic update included more encouragement for guide owners to use a photo in their profiles. Profile pictures had been used inconsistently in the first LibGuides interface, and several guide owners used the default grey avatar. Guide owners who were reluctant to have a headshot on their profile were encouraged to take advantage of stock photos made available through the Naval Academy's Public Affairs Office. A photo shoot was also organized for guide owners. On a voluntary basis, guide owners spent about an hour helping each other to take pictures in and around the Library. The event helped to get a collection of more professional photos for guide owners to choose from.

Another important update was the re-evaluation of LibGuides policies in light of the new functionality available in version 2 . The guide owners gathered for a meeting midway through the pre-migration guide cleanup process to troubleshoot problems and consider best practices for the 
new interface. Guide owners discussed the standardization of tab names in the guides, the information important to include in author profile boxes, and potential categories for the "types" dropdown in the A-Z database list. The meeting provided a great opportunity to discuss the options available to guide owners and to solicit feedback on interface mock-ups and guide templates created by the Systems Librarian. Many items from the discussion were incorporated into the update LibGuides policies for guide owners.

\section{LibAnswers and LibChat Teams}

Integrating LibAnswers with LibChat, an additional Springshare product, at the same time as the migration to LibGuides version 2 is not necessary. Because the acquisition of LibAnswers coincided with the need to upgrade to version 2 , the Library staff determined that the two should be done at the same time in order to minimize disruption for patrons. The ad hoc teams tasked with implementing LibAnswers and LibChat met regularly to learn about the new products and to consider how these products would fit into the library's existing points of service. While the LibAnswers and LibChat teams began as two distinct groups, it became increasingly clear that the functionality of these two systems is interwoven so closely that they must be reviewed and discussed together. The teams spent considerable time learning the functionality of the new systems, considering how the new service points would integrate into the existing offerings, and creating draft policies to provide guidance to staff. The teams developed a set of tips and guidelines to address staff concerns and provide guidance on how the new system should be used (see Appendix C). The teams also held training sessions focused on providing opportunities for staff to explore and practice using the new products. Although the implementation of LibAnswers with LibChat was not necessary to upgrade to LibGuides version 2, undertaking all of these upgrades at once allowed the ad hoc groups to collaborate with ease, define policies and procedures that would help these products integrate seamlessly with existing services, and prevent change fatigue within the Library.

\section{Updating the Library Website}

The final element of migration and implementation the teams had to consider was integration into the Library's existing web site. Many elements of the Library's site are dictated by the broader university web policy and content management system. However, working within guidelines the teams were able to take advantage of the new LibGuides interface, especially the more robust A-Z list of databases, to provide users with multiple ways of accessing the new tools. The Library makes use of a tabbed box to provide entry to Summon, the catalog, the list of databases and LibGuides. The new functionality of LibGuides version 2 enabled the team to provide easier access directly to the alphabetical listing of databases. The LibGuides tab was also updated to provide a drop down list of all the guides and a link to browse by guide owner, subject or type of guide. These enhancements saved time for the user and cut down on the number of clicks needed to access database content licensed by the library. 
Integrating the LibAnswers product into the site was achieved by providing several different ways for patrons to access it. An FAQ tab was added to the main tabbed box to provide quick access to LibAnswers, complete with a link to submit questions. The "Contact Us" section on the site home page was updated to include a link to LibAnswers as well as newer, more modern icons for the different contact methods. All guide owners were instructed to update the contact information on their guides to include a LibAnswers widget.

A great source of inspiration on integrating the tools into the Library site came from looking at other library web sites. The teams worked from the list of LibGuides community members provided on the Springshare help site and by viewing the sites of known peer libraries. Working through an unfamiliar web site can be a quick way to find design ideas and work flows that are successful and attractive. Team members found wording, icons and placement ideas that could be adapted for use on the Nimitz Library site.

\section{Advice for Managing a Short Migration Timeline}

While on a short implementation timeline or with a small staff that has to accomplish this project in addition to their regular duties, it's important to consider a few strategies that can make the process simpler and less stressful. First, communicate expectations with everyone involved in the project at all steps of the process. Determine which stakeholders need to know about the various checklists and upcoming deadlines. Communicating needs and expectations throughout the entirety of the project reduces confusion and enables teams and individual guide owners to complete the project on time. Although LibGuides had predominantly been the domain of the Nimitz Reference Department, projects of this scale also impacted other parts of the library, from systems to the Electronic Resources librarian. Email communication and short notices in the Library's weekly staff update were the primary means of communication with stakeholders. Documents were shared via Google Drive to provide guide owners with a centralized file of help materials. Also, the point of contact for questions with each element of the migration was clearly identified on each checklist and tip sheet. This single addition to the checklists helped guide owners to quickly and easily get questions and technical issues addressed.

On a short timeline it is also important to consider the elements that are crucial for completion and those that can be delayed. Some critical needs in a LibGuides migration include deleting guides that are no longer being used, checking for boxes that will not migrate and deleting bad links. These tasks must be completed by guide owners or administrators to ensure that the migrated data formats properly. Careful attention to these tasks also save the staff unnecessary work on updating and fixing the new guides before going live. Other elements of guide design and migration are merely nice to have. They complement the user's experience with the final product but neglecting them will not affect basic functionality. These secondary tasks can be completed as time allows. For guide owners, optional tasks include shortening link descriptions, checking for a 
guide description and friendly url and other general updates to the guides. The migration was broken into manageable tasks by giving guide owners a clear list of required and optional items.

Team leaders will also need to manage expectations. It can be difficult to remember that web pages, especially LibGuides, are living documents. They can be updated fairly easily after the system has gone live. On a short timeline, in the midst of other duties and responsibilities, it is acceptable for a guide to be just good enough. There is rarely enough time for each guide to reach a state of perfection prior to going live. A guide that is spell-checked and contains accurate information can be edited and made more aesthetically pleasing as time allows after the entire site has gone live. While additional edits are taking place, students still have access to the information they need for their academic work. Lists, such as the subjects and material types in the A-Z list, are always a work in progress based on feedback from service points and usability testing. Updates and edits should be made as patrons interact with the products. Regular use can help library staff identify problems with or confusion about the products that might not be anticipated prior to going live. Stress on guide owners can be greatly reduced by communicating expectations throughout the process.

\section{Post-Implementation}

Nimitz Library successfully went live with both LibGuides version 2 and LibAnswers with LibChat in early January 2016, right before midshipmen returned to campus for the Spring semester. LibAnswers with LibChat was introduced to the campus community with a soft launch at the beginning of the Spring semester due to staffing levels and shifts at the reference desk. The librarian on duty at the reference desk was also responsible for answering any chats or LibAnswers questions initiated during their shift. The volume of questions remained fairly low during the semester. On average, the Library received two synchronous and 1.5 asynchronous incoming questions per week via LibAnswers with LibChat. The low volume was beneficial in that it allowed librarians to become familiar with answering questions and editing FAQs. They were able to handle both face-to-face interactions with patrons in the library and the web traffic. However, the volume was so low that it became apparent more marketing of the service was needed. At the start of the fall 2016 semester, the library made an effort to increase awareness of the new LibAnswers products by emailing all students, mentioning the service in every instruction session, and creating fliers advertising the service and distributing them around the library. Though data is preliminary, statistics have shown that use of these services has more than tripled in the first month of the new semester.

As discussed above, the expedited implementation timeline forced the ad hoc teams to prioritize completion of the tasks that were necessary for the system to remain functional after the upgrade. This meant other necessary, but not urgent, updates to guides were left untouched during the migration. Given the amount of effort needed to prepare the guides for migration, it is understandable that guide owners had grown tired of making LibGuides updates and found it 
necessary to move on to other projects. With this fatigue in mind, the team leaders will continue to remind guide authors that LibGuides are living pages in need of constant attention. The team leaders will also take advantage of user feedback to promote continued updates to LibGuides.

Throughout the migration process team leaders solicited feedback from staff and users in a variety of ways. First, reference staff wereinformed of design and implementation changes made throughout the migration. They were given time to view and evaluate the master guide template prior to the migration. The team solicited feedback on the names and organization of categories in the A-Z list. After the products went live, the team gathered informal feedback through reference desk interviews, in information literacy instruction sessions and in conversations with faculty and students. Student volunteers participated in usability testing during the Spring semester. They were asked to complete a series of tasks related to the different aspects of the new interface. Their feedback, especially from thinking aloud while completing the tasks, revealed to librarians how students actually use the guides. Both formal and informal feedback helped librarians adapt and improve the guides. Based on the feedback, the Systems Librarian made global changes to improve system functionality. In one instance, users were having difficulty submitting a new LibAnswers question when they could not find an appropriate FAQ response. The Systems librarian made the "Submit Your Question" link more prominent for users in that situation. The LibGuides continue to be evaluated by staff for currency and ease of use. In discussing the first round of usability test results it was determined that more testing during the Fall semester of 2016 would be helpful.

During the upgrade to version 2 and implementation of LibAnswers with LibChat, librarians focused on the functions in the system that were most essential or most desired. All of these products contain additional functionality that was not implemented during the upgrade. After a brief rest, the reference department and library web team explored the products' additional functionality and determined what avenues to explore next.

\section{CONCLUSIONS}

Migration of any platform can be an extensive and time consuming task for library staff. Preparations and post-migration clean up can interrupt staff workflows and strain limited resources. Using migration teams was a successful strategy on a short timeline because it helped spread the workload by delegating specific learning and tasks to specific people. Those people, in turn, became experts in their area of focus and served as a resource for others in the library. This model cultivated a sense of ownership in the migration across many stakeholders that might not have otherwise existed. That sense of ownership in the project, coupled with checklists and spreadsheets full of discrete tasks in need of completion made it possible for a small staff to complete the migration quickly and successfully. Migrating on a short timeline can be especially stressful but careful planning and good communication of expectations helps stakeholders focus on the end goal. Upon completion of the project there was a very real sense of fatigue with this 
project. As a result, tasks that were listed as optional because they weren't critical for migration went unattended for quite some time after the migration. Slowly, months later, guide owners are ready to revisit guides and continue making improvements.

If given more time, this migration may have been completed more methodically and with the intent of having everything perfect before moving on to the next step. Instead, working on a tight timeline forced us to continue moving forward, making necessary changes, and making note of changes to be made in the future. Ultimately, it was a constant reminder that our online presence is and should be a constant work in progress, not the subject of a big, occasional update.

\section{REFERENCES}

1. Luke F. Gadreau, "Migration checklist for guide owners," last modified April 3, 2015, https://wiki.harvard.edu/confluence/display/lg2/Migration+Checklist+for+Guide+Owners; Leeanne Morrow et al., "Best Practice Guide for LibGuides," accessed November 17, 2016, http://libguides.ucalgary.ca/c.php?g=255392\&p=1703394; Rebecca Payne, "Updating LibGuides \& Preparing for LibGuides v2," last modified November 18, 2014, https://wiki.doit.wisc.edu/confluence/pages/viewpage.action?pageId=85630373; Julia Furay, "Libguides Presentation: Migrating from v1 to v2 (Julia)," last modified September 29, 2015, http://guides.cuny.edu/presentation/migration.

2. Anna Burke, "LibGuides 2: Content Migration is Here!" last modified April 30, 2014, http://blog.springshare.com/2014/04/30/libguides-2-content-migration-is-here/; Springshare, "On your Checklist: Five Tips \& Tricks for Migrating to LibGuides v2," last modified February 18, 2016; http://buzz.springshare.com/springynews/news-27/springytips; Springshare, "Migrating to LibGuides v2(and going live!)," last modified November 7, 2016, http://help.springshare.com/libguides/update/whyupdate.

3. Lauren McKeen and John Hernandez, "Moving mountains: surviving the migration to LibGuides 2.0," Online Searcher 39 (2015): 16-21, http://www.infotoday.com/OnlineSearcher/Articles/Features/Moving-Mountains-Survivingthe-Migration-to-LibGuides--102367.shtml.

4. Vicky Duncan et al., "Implementing LibGuides 2: an academic case study," Journal of Electronic Resources Librarianship, 27 (2015): 248-258, https://dx.doi.org/10.1080/1941126X.2015.1092351

5. Jimmy Ghaphery and Erin White, "Library use of web-based research guides," Information Technology and Libraries 31 (2012): 21-31, http://dx.doi.org/10.6017/ital.v31i1.1830; Danielle A Becker; "LibGuides remakes: how to get the look you want without rebuilding your website," Computers in Libraries 34 (2014): 19-22, http://www.infotoday.com/cilmag/jun14/index.shtml; Michal Strutin, "Making research guides 
more useful and more well used," Issues in Science and Technology Librarianship 55(2008), https://dx.doi.org/10.5062/F4M61H5K.

6. Ning Han and Susan L. Hall, "Think Globally! Enhancing the International Student Experience with LibGuides," Journal of Electronic Resources Librarianship 24(2012): 288-297, https://dx.doi.org/10.1080/1941126X.2012.732512; Gabriela Castro Gessner et al., "Are you reaching your audience?: The Intersection Between LibGuide Authors and LibGuide Users," Reference Services Review 43(2015): 491-508, http://dx.doi.org/10.1108/RSR-02-2015-0010.

7. Luigina Vileno, "Testing the usability of two online research guides," Partnership: The Canadian Journal of Library and Information Practice and Research 5 (2012), https://dx.doi.org/10.21083/partnership.v5i2.1235; Rachel Hungerford et., "LibGuides usability testing: customizing a product to work for your users,"

http://hdl.handle.net/1773/17101; Alec Sonsteby and Jennifer DeJonghe, "Usability testing, user-centered design, and LibGuides subject guides: a case study," Journal of Web Librarianship 7(2013): 83-94, https://dx.doi.org/10.1080/19322909.2013.747366.

8. Mardi Mahaffy, "Student use of library research guides following library instruction," Communications in Information Literacy 6(2012): 202-213, http://www.comminfolit.org/index.php?journal=cil\&page=article\&op=view\&path\%5B $\% 5 \mathrm{D}=\mathrm{v}$ $\underline{6 i 2 p 202 .}$

9. Kate A Pittsley and Sara Memmot, "Improving Independent Student Navigation of Complex Educational Web Sites: An Analysis of Two Navigation Design Changes in LibGuides," Information Technology and Libraries 31 (2012): 52-64, https://dx.doi.org/10.6017/ital.v31i3.1880. 


\section{Appendix A: LibGuides Pre-Migration Checklist}

If there are issues, contact the Head of Reference \& Instruction.

Required before migration:

\begin{tabular}{|l|l|l|}
\hline Due Date & Task & $\begin{array}{l}\text { Check } \\
\text { when } \\
\text { Complete }\end{array}$ \\
\hline $\begin{array}{l}26 \\
\text { October } \\
2015\end{array}$ & $\begin{array}{l}\text { Review attached report of guides that have not been updated } \\
\text { in the last year. Delete or consolidate unneeded, practice, or } \\
\text { backup guides.* }\end{array}$ & \\
\hline $\begin{array}{l}26 \\
\text { October } \\
2015\end{array}$ & $\begin{array}{l}\text { Review attached report of guides with fewer than 500 hits. } \\
\text { Delete or consolidate unneeded, practice, or backup guides.* }\end{array}$ & \\
\hline $\begin{array}{l}26 \\
\text { October } \\
2015\end{array}$ & $\begin{array}{l}\text { Review all links to all databases included on your guides and } \\
\text { make sure the links are mapped to the A-Z list. }\end{array}$ & \\
\hline $\begin{array}{l}26 \\
\text { October } \\
2015\end{array}$ & $\begin{array}{l}\text { Review all guides for links not included in the current A-Z List. } \\
\text { moving forward on the shared spreadsheet (A-Z Additions } \\
\text { and Best Bets). Be sure to include all necessary information, } \\
\text { including subject and type. }\end{array}$ & \\
\hline $\begin{array}{l}\text { Mid- } \\
\text { October } \\
2015 \text { \& } \\
\text { October } \\
2015\end{array}$ & $\begin{array}{l}\text { Review forthcoming reports about broken links. Anticipate } \\
\text { one report on October 13, and one October 26. }\end{array}$ & \\
\hline $\begin{array}{l}\text { Review the Databases by subject page of the A-Z list and make } \\
\text { sure everything that should be included in your subject is } \\
\text { there. Add anything you'd like removed from your subject to }\end{array}$ & \\
\hline
\end{tabular}




\begin{tabular}{|c|c|}
\hline & $\begin{array}{l}\text { the shared spreadsheet (tab 2). } \\
\text { Identify } 3 \text { "best bets" databases for each of your subject areas } \\
\text { on the shared spreadsheet (tab } 3 \text { ). }\end{array}$ \\
\hline $\begin{array}{l}26 \\
\text { October } \\
2015\end{array}$ & Ensure all images have an alt tag \\
\hline $\begin{array}{l}26 \\
\text { October } \\
2015\end{array}$ & Delete outdated or unused images in your image collection \\
\hline $\begin{array}{l}26 \\
\text { October } \\
2015\end{array}$ & Convert all tables to percentages, not pixels \\
\hline $\begin{array}{l}26 \\
\text { October } \\
2015\end{array}$ & $\begin{array}{l}\text { Review attached report of boxes that will not migrate into } \\
\text { version } 2 \text {. (This won't apply to everyone) }\end{array}$ \\
\hline $\begin{array}{l}26 \\
\text { October } \\
2015\end{array}$ & $\begin{array}{l}\text { Email the chair of the Web Team if you have guides with boxes } \\
\text { containing custom formatting or code (this is only necessary if } \\
\text { you manually adjusted the HTML or CSS, or use a tabs within a } \\
\text { box on your guide). We are keeping a master list to double } \\
\text { check after migration. }\end{array}$ \\
\hline $\begin{array}{l}26 \\
\text { October } \\
2015\end{array}$ & $\begin{array}{l}\text { Check all links to the catalog in your guides to make sure they } \\
\text { are accurate }\end{array}$ \\
\hline $\begin{array}{l}26 \\
\text { October } \\
2015\end{array}$ & $\begin{array}{l}\text { Check all widgets (like catalog search boxes) to ensure they } \\
\text { function properly, delete any widgets you don't need, and keep } \\
\text { a list of widgets to check post-migration to make sure they still } \\
\text { function. }\end{array}$ \\
\hline
\end{tabular}


Optional before migration:

\begin{tabular}{|l|l|l|}
\hline Due Date & Task & $\begin{array}{l}\text { Check when } \\
\text { Complete }\end{array}$ \\
\hline & $\begin{array}{l}\text { Consider turning links in 'rich text' boxes to a 'links and list' } \\
\text { box. }\end{array}$ & \\
\hline & $\begin{array}{l}\text { Review all guides to ensure they have a friendly URL, are } \\
\text { description. }\end{array}$ & \\
\hline & $\begin{array}{l}\text { Shorten database descriptions to one to two sentences. } \\
\text { Consider including dates of coverage and why it's useful for } \\
\text { this particular subject. }\end{array}$ & \\
\hline
\end{tabular}

Helpful hints:

*If you'd like to hold on to content from guides you plan to delete, create an unpublished "master guide" where you can store content you plan to use in the future. 


\section{Appendix B: LibGuides Post-Migration Checklist and Guide Clean up}

NOTE: Now that migration is complete, if you make an update to your version 1 guides, your change will not transfer to version 2 . This means broken links will need to be fixed in both versions. If there are issues or questions contact the Head of Reference \& Instruction (general questions), the Systems Librarian (technical issues), or the Electronic Resources Librarian (database assets and A-Z list).

\section{CLEAN UP AND CHECK CONTENT}

1) Check boxes to make sure content is correctly displayed on all your guides. Check all boxes closely, as some had the header end up below the first bullet point. For example:

To fix an issue like this - Click on \% Add / Reorder * at the bottom of the box

Aerospace Design : Aircraft, Spacecraft, and the Art of Modern Flight by Anthony M. Springer

Call Number: Oversize Book Stacks TL546 .A376 2003

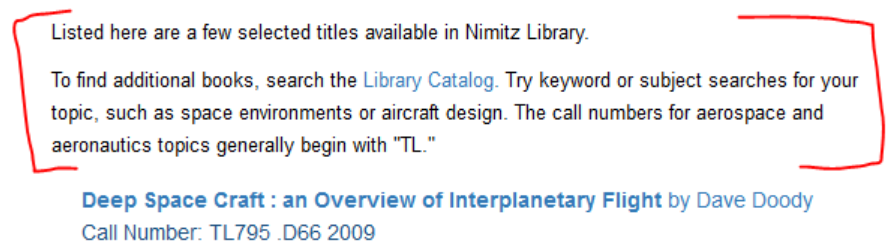

you are working on. Then click on "Reorder Content". You can move the links down and the text up

2) Ensure all guides have a friendly URL, are assigned to a subject, have assigned tags if you didn't do this pre-migration. See the premigration handout for help. In version 2 this information will display at the TOP of our guides in edit mode and at the BOTTOM of our guides on the public interface.

3) Ensure images are resized to fit general web guidelines - See this guide for help http://guidefaq.com/a.php?qid=12922

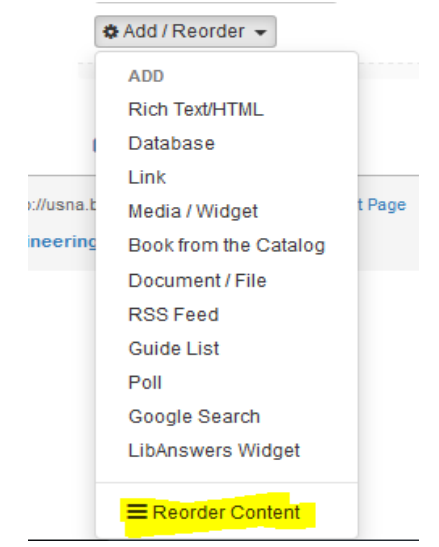

4) Check all your widgets to ensure they still function properly

5) Add a guide type to each of your guides. This is a new feature in LibGuides version 2. It is under the gear on the right side of your guide while in edit mode. This will help us sort and organize them in the list of guides.

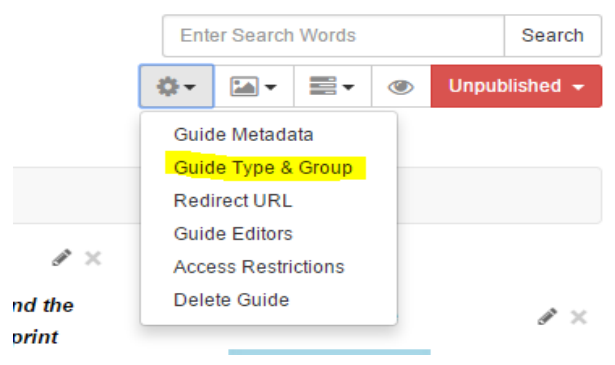




\section{ADD NEW LIBGUIDES 2 CONTENT}

1) Make a box pointing to related guides. Research has shown that a box on the guide home page pointing to related guides can be very helpful to students. Link to other subject guides that would be of interest and any course guides for that subject. For example: the box on the Mechanical Engineering guide contains links to EM215 and Nuclear Engineering (which is part of the Mechanical Engineering department).
Welcome!

This guide will help you find relevant information for your research on different aspects of mechanical engineering and material sciences.

Questions, feedback or recommendations for the collection? Please contact Brianna Buljung, Engineering Librarian

This guide is intended for use by midshipmen and faculty of the U.S. Naval Academy and links should not be interpreted as endorsements.

Related Guides

- Nuclear Engineering

by Brianna Buljung Last Updated Nov 13, 201518 views this year

- EM215 Introduction To Mechanical Engineering

by Brianna Buljung Last Updated Nov 13, 201519 views this year

- EM313 Materials Science

by Brianna Buljung Last Updated Nov 13, 20150 views this year

To do this - go to the bottom of your welcome box, click the Add/Reorder button, and then on Guide List, your first option is to manually choose guides to add to the list.

2) Add a tab to every guide that is named Citing Your Sources and redirects to the Citing Your Sources LibGuide. To do this:

a. Create a blank page named Citing Your Sources at the bottom of your left side navigation

b. On your blank page click on the क्ष PAGE open the options for editing the page.

c. Click on Redirect URL and paste the link to the Citing Sources guide in the box.

d. It is also a good idea to mark the open in a new window box as well to - Add/Reorder ADD Rich TextHTML Database Link Link Media / Widget Book from the Catalog Document/File RSS Feed Guide List Poll Google Search at place Lanswers Widget EReorder Content research 
f. Finally, REMOVE the plagiarism and citing sources box from your guides.

3) Now is a good time to take advantage of new functionality and to update the content of your guides. You can now combine multiple types of information into the same box, you can also take advantage of tabbed boxes. See this LibGuide for further assistance:

http://support.springshare.com/libguides/migration/v2cleanup-regular

4) Create your new Profile Box

At the meeting on Oct 20th, the Reference \& Instruction department agreed that the following elements should be consistent in the profile box:

Box Name: Librarian

Image: A stock photo or a personal photo (picture day coming soon)

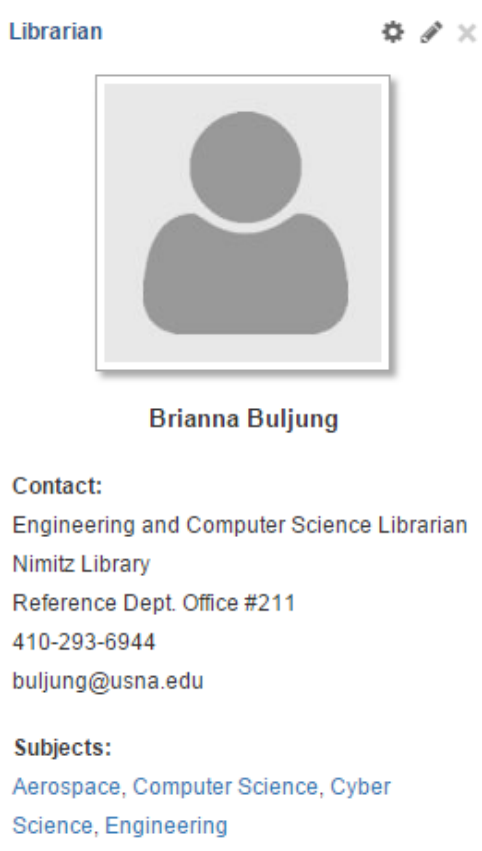

And your subjects will be displayed below 


\section{Appendix C: Tips \& Guidelines for LibAnswers with LibChat}

\section{WHAT MODES OF INQUIRY WILL BE AVAILABLE TO USERS?}

Using the LibAnswers platform, users will be able to submit questions via chat or by using the question form within LibAnswers. Users will also be able to ask questions as they did before: at the reference desk, via askref@usna.edu, and by calling 410-293-2420.

\section{WHAT ARE “BEST PRACTICES” OR GUIDELINES FOR LIBANSWERS W/LIBCHAT?}

See the tips for responding to tickets at the bottom of this document.

See the tips for creating/maintaining FAQ at the bottom of this document.

See the tips for responding to chat questions at the bottom of this document.

\section{WHAT PRIORITY SHOULD I GIVE RESPONSES COMING THROUGH VARIOUS MODES OF INQUIRY?}

Reference staff will have to use their professional judgement when deciding what priority to give questions coming in through various modes of inquiry. While the addition of chat and tickets may seem overwhelming at first, the same rules you've applied in the past will work. If a chat comes in while you're helping someone face-to-face, use that as an opportunity to advertise the chat service. Explain to the patron that you also help users via chat and you're going to let the chatter know that you'll be with them shortly. The same can apply if you're finishing up a chat when a face-to-face user walks up. Simply explain that the library also offers a chat service and you're just finishing up a question. Remember to get comfortable with and take advantage of the canned messages in chat, let the phone go to voicemail if necessary, and explain to face-to-face users what's happening. During the pilot phase you should also keep track of strategies that worked well for you, or times when the various modes of inquiry became too overwhelming. We'll take all of that into consideration when we reexamine this service.

Chat, phone, and face-to-face interactions are synchronous modes of communication, so users expect responses immediately. Tickets are asynchronous modes of communication and should be dealt with on a first come, first served basis. Respond to tickets when you have time. When responding to tickets, respond to the oldest tickets first as that user has been waiting the longest for an answer. However, feel free to use your judgement and, if you choose, respond to questions with quick answers right away.

\section{HOW SHOULD I PRIORITIZE QUESTIONS FROM USNA V. NON-USNA USERS?}

Priority should be given to midshipmen, faculty, and staff. If an outside user makes use of the chat or ticket service, feel free to explain to them that this service is primarily for faculty/staff/students and they should direct their question to askref@usna.edu. If you are free and have time, feel free to assist outside patrons via the chat or ticket system. 
HOW SHOULD I HANDLE REMAINING QUESTIONS DURING A CHANGE IN SHIFTS?

Handle them in the same manner that you would a face-to-face question with a student, faculty, or staff member. Finish up quickly if you can, advise the patron that you need to leave and offer to handle the question when you return, or transfer the chat to another librarian. If there are remaining tickets in the queue, simply notify the next librarian on duty.

\section{WHAT ARE THE EXPECTED TURNAROUND TIMES FOR RESPONDING TO PATRON INQUIRIES?}

Chat, face-to-face, and phone inquiries should be responded to as immediately as possible. Tickets should be responded to within a business day.

\section{WHO CAN I CONTACT FOR HELP AND TROUBLESHOOTING?}

If you have questions, your first stop should be the LibAnswers FAQ, provided by Springshare (available in the "Help" section when logged into LibApps). If you can't find the answer to your question there, feel free to contact the Head of Reference and Instruction, who will work to resolve the problem with you.

\section{GUIDELINES FOR RESPONDING TO LIBANSWERS TICKETS*:}

- Keep in mind that when you are responding to tickets, you are a jack of all trades. That means even if the question is outside of your subject area, you should do your best to provide the user information that will get them started. In that email you may also suggest that the user contact the subject specialist.

- Respond to LibAnswers tickets in the same way you would respond to an email inquiry from a user.

- If you provide a factual response, be sure to include the source from which that information came.

\section{Guidelines For Creating/Maintaining FAQs*:}

- The FAQ database is a public-facing, searchable collection of questions and answers. The intent is to empower our users to find their answers. Any question that might be considered a frequently asked question should be included in the FAQ. This might include questions about the library, the collections, how to find specific types of information, how to start research on specific and recurring assignments etc.

- When creating an FAQ from a ticket, remember that you can edit the question. Do your best to format the question in a way that would be applicable and relevant to the most users.

- When creating an FAQ from a response you've already written, be sure to edit out any personally identifiable information (PII) about the person who initially asked the question. Be sure to check the question and response for any PII. 
- If you want to modify an FAQ: If a member of the staff notices incomplete or incorrect information in an FAQ response, he/she should use professional judgement in deciding how to handle the situation. If it's an error that may have been caused by a typo, he/she may choose to edit the response immediately. However, if the edit impacts the substantive content of the response, he/she may choose to consult with the librarian who initially wrote the response.

\section{GUIDELINES FOR LIBCHAT*:}

- If you refer a question, alert the librarian to whom the user is being referred.

- Remember the person you're chatting with can't see you so if you leave (to conduct a search, to check a book, to help someone else etc.) let them know you'll be right back.

- Sometimes chat questions can seem rushed, so it may be tempting to answer the initial question. Remember, like face-to-face interactions, clarifying queries save time for the user and the librarian, allowing for the provision of more accurate and efficient answers.

- When providing responses, remember that as an academic library, our mission is to provide the information needed and to instruct our users so they may become self-reliant; Chat challenges us to balance providing answers and instruction. Do your best to find an appropriate balance.

- As the transaction is ending, remain courteous, check that all the user's questions have been addressed, and encourage them to use the service again.

* Note: These Guidelines are drafts and will evolve as the staff learns more about this system throughout the pilot phase. 